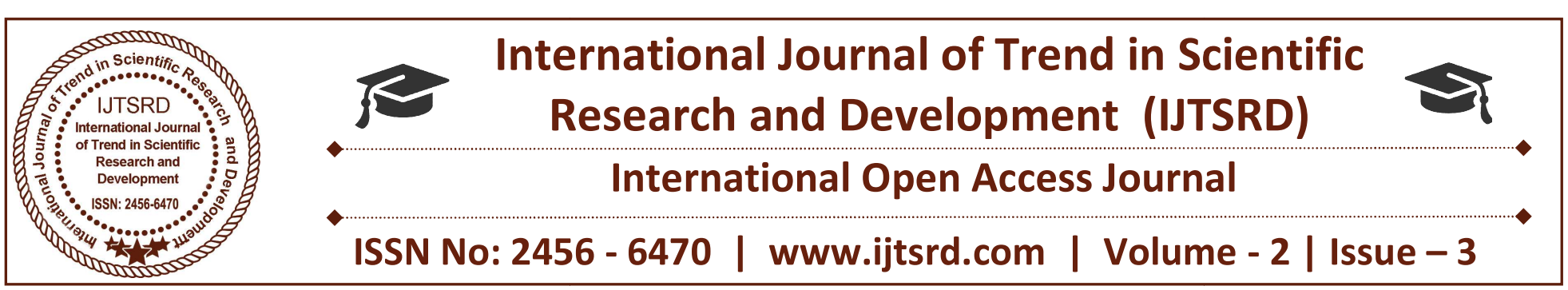

\title{
Importance International Financial Management Finance
}

\author{
Arelli Ankitha \\ MBA Finance, Pragathi School of Information Technology, \\ Hanamkonda, Telangana, India
}

\begin{abstract}
Quick globalization, the financial crisis and the everchanging business environment make the current financial management more complicated than ever. Since the financial decisions taken by the International Finance Management (IFM) have taken place, the same forces make successful financial controls so important. The development of international trade is evident in the high inflationsized mode of international trade. The history of international trade can be traced after World War II. Trade agreements have been made on trade and tariffs to increase trade immediately after the war. This establishment removes widespread trade restrictions over the years, and as a result, multinational trade has increased. In addition, the financial assistance of trader on exports and imports extends to countries extensively. Since then, this situation will continue to stimulate all kinds of and sizes companies to think about how to use resources when dealing with international markets. This expansion increases significant variation in the condition of market stability. As a result, major financial decisions today lead to border issues. All other factors in investment, risk management, investment decisions, mergers, rebuilding and economic strategy are usually international complexes and these issues increase the need for international financial management. When the financial organizers make these decisions, they should consider currency conversion rates, risky factors of the particular country, variation in tax rules, and devaluation in legal systems. In short, financial managers of multinational corporations and international financial management are most

\section{INTRODUCTION}

\section{Goals}

The purpose of this international research paper is to discuss the importance of international financial management and to know the role of financial management in the modern international business environment.

\section{Importance of International Financial Management}

The importance of international finance management (IMF) is not exaggerated. This is a major factor for successful business operations. No organization has achieved full potential for success and growth as there is no financial in the local market in the local market. Money is called the Worldwide Lubricant, which puts in the development of local and multinational business products, managing machines and men in work, managing to create values and progress. I have discussed globalization to open up markets for major companies in the international markets, but have also brought corporate companies to a variety of risks they face while working in the international era, and international financial management in this regard should reduce these losses and publicly open corporations worldwide. The risk factors faced by multinational corporations and the role of international financial management will play the role of controlling this risk of increasing international economic management.
\end{abstract} important and are discussed in detail below.

Keywords: globalization, financial, Management, currency conversion, legal.

Currency Exchange Risk and International Financial Management 
Operating business in international markets may lead to a foreign currency exchange risk, called transaction exposure. The currency exchange risk is either an entity or a major component of foreign currency (FC). The risk of diversification of the foreign currency exchange rate continues. For example, if the value of foreign currency increases before the liability is paid, the business will have to pay the extra amount of foreign currency required to clear this obligation. Consequently, the business loses currency. And the foreign currency of the business will be beneficial when the value of the currency decreases. On the other hand, net assets have reverse relationships, which are categorized into foreign currency.

Maintaining a currency exchange risk, IFM policies have become more prominent in recent years. IFM provides different limitation methods to control foreign currency transaction risk.

\section{Price}

Primary technology provides international finance management to control risk or control the billing currency, the price is called. Companies can control the Exchange Risk Currency if their clients are in the Company Reporting Currency or Functional Currency. For example, a business can resolve the price of the receivables in the currency they are reporting, and thus transfer the exchange risk to their customer.

\section{Settlement}

This technology can be used when a business can not afford a customer in reporting currency, which can use a settlement technique to eliminate risk of FC exchange. Management of this technology will provide early settlement discounts for payments that can be constantly paid in a foreign currency or payable. In short, this policy of IFM pushes a business to reject the benefit of money-time value with the intention of avoiding losses in foreign currency exchange differences.

\section{Forward Contracts}

Other methods must be used to control cash flows, which should not make an initial settlement or price in reporting currency. In this situation, the popular limiting methods are selling and buying contracts in foreign currency. These contracts between parties to sell or buy foreign currency at the forefront at a fixed fixed exchange rate. It reduces variation company exposures to conversion rates, no future rate, transactions occurring at fixed rate. Currency exchange cost and forward contract purchase price in this transaction.

\section{Leading and logging}

IFM also provides additional technology to reduce losses for centralized and large businesses, known as popular and logging. In this method the amount required to pay (prepayment) against the payment currency and when the payer's currency increases, the payments are deducted against the payment currency. From the business perspectives, the International Financial Manager asks a leading and backward approach to the purpose of constructive consequences of exchange rate variation. Furthermore, major and backward tactics can be implemented to move cashto-poor funds from cash-based partners, thereby increasing liquidity for a short-term.

\section{Working capital management and international financial management}

International financial management work plays an important role in capital management. Capital management means making short-term liquidity and decision making decisions on capital financing. These decisions are to organize awareness between shortterm asset and small responsibilities of the company. In this regard, it will play a significant role by increasing the value of the international financial management company, and the cost of such projects will be a favorable net present value (NPV) with a discounted rate. As a result of these investments, capital will have complexities with the cost of cash pf cash flows. The purpose of the IFM is to maintain the business and ensuring positive flow of cash that supports long-term loans and ensuring upcoming operating expenses and short-term debt. In this way, if the return on capital investments and the cost of capital expanses, the value of the firm is valuable.

\section{Financing decision}

Financial Management Guides companies in financing divisions and achieving business financing goals IFM requires any corporate investments to be properly equipped. Valuation can affect the financing mix while discussing the effect of both un-fixed rate 
and cash flows. In this way the financial organizer must highlight the proper mix of capital structures and financing, which can lead to a maximum value. The sources for generating financial resources usually have a combination of debt and equity financing. If a business is determined to be financed by a loan, it will increase the obligation to pay, so the project's goal of success consists of cash flow problems independently. Second choice equity financing. However, equity financing is less dangerous for cash flow payments, but results in reduction in control, management and earnings. The cost of equity financing is more than the cost of debt financing, and in this way the equity financing method can result in a appreciative hurdle rate to compensate for any reduction in cash flow risk. Management of International Financial Management helps to keep balance between two options to avoid cost burden.

\section{IFM coordinates various functional functions}

Integrating comprehensive international financial management among the functional areas such as production, marketing, etc. to accomplish the goals of organizations. If financial management in multinational companies is incomplete, the effect of other business units can be managed. For example, the Finance Department needs the necessary finance for the procurement of raw materials and the need for other expenses to maintain a successful business. If the financial sector does not work properly and can not meet the obligations, the sale and product segments are lost, resulting in profit and income. In short, proper financial management occupies an important place in any business concern.

\section{Determining business success}

International financial management requires business success. It is noted that financial managers will play an important role in economic success by all financial experts allowing high-level solutions to financial solutions. In relation to the financial status and specific periods, the company provides substantial statistics and facts with the performance of various tasks, making it easier for higher management to evaluate the company's progress to properly address the organization's management policies and the organization's principles. International financial organizers can help in the management of the decision-making process by recommending the best solutions from the number of alternatives available.
Hence international financial management can help in managing various national and international economic decisions.

\section{Measure of IFM performance}

The International Financial Management Ratio Analysis System helps to measure business performance through its financial results. These analyzes provide the location where the company is per year. Recognizing losses, such financial decisions reduce the value of the company on the other side, such international financial decisions that increase profitability improve company value. Two important components of profitability and risk in any business that effectively manage through financial management.

\section{Conclusion}

The challenges facing today's management are internationally powered, efficient and efficient. The major difficulties facing the business in international markets, the change in currency exchange rate, investment decisions, financing decision, and the coordination of different business segments in different geographical areas. These problems can be managed by the proper adaptation of international financial management practices. These methods are based on the understanding of management of the needs of overseas markets and its subsidiaries. In short, management business accounts and finance are crucial to multinational business success because of the complexity of financial management in the international business environment and the importance of financial management challenges international management 